\title{
Sarcoptic mange in red deer from Spain: Improved surveillance or disease emergence?
}

\author{
A. Oleaga ${ }^{\mathrm{a}, \mathrm{b}}, \mathrm{R}$. Casais ${ }^{\mathrm{b}}$, P. González-Quirós ${ }^{\mathrm{c}}$, M. Prieto ${ }^{\mathrm{b}}$, C. Gortázar ${ }^{\mathrm{a}, *}$ \\ ${ }^{a}$ IREC (CSIC-UCLM-JCCM), Ronda de Toledo s/n, 13071 Ciudad Real, Spain \\ ${ }^{\mathrm{b}}$ SERIDA (Servicio Regional de Investigación y Desarrollo Agroalimentario), \\ Laboratorio de Sanidad Animal, Jove, Gijón, Asturias, Spain \\ ${ }^{\mathrm{c}}$ Biogestión, Consultora medioambiental, C/Coronel Aranda $N^{\circ}$ 7, $5^{\circ}$ Izda. 33005 Oviedo, Asturias, Spain \\ Received 13 December 2007; received in revised form 28 February 2008; accepted 4 March 2008
}

\begin{abstract}
Concern about emerging diseases has risen in recent years, and multihost situations have become increasingly relevant for wildlife management and conservation. We present data on Asturias, northern Spain, where 80 mangy red deer (Cervus elaphus) have been found since the beginning of the epizootic in chamois (Rupicapra pyrenaica parva) in 1993. We combine field and necropsy data with the results of a serosurvey using an in-house ELISA test to evaluate if deer mange due to Sarcoptes scabiei is an emerging disease in this area. The mean number of deer mange cases per year was 5, with a maximum of 16 . No significant relationship was detected between monthly temperatures, rainfall or number of days with snow cover and the annual number of sarcoptic mange cases in red deer. Only 4 mangy red deer (5\%) were detected outside the limits of scabietic chamois distribution during the same year, and all were less than $2500 \mathrm{~m}$ away from that limit. The longest distance reported between two consecutive mangy deer locations was $18 \mathrm{~km}$. Mange cases were significantly more frequent in stags than in hinds and in adults than in juvenile deer. The time of the first mange detection in chamois in each sector, year with minimum number of chamois recorded, year with maximum chamois population decline rate and chamois density offered no significant correlation with red deer mange cases appearance moment and frequency. In the mange affected area, ELISA testing of 327 blood samples from hunter-harvested deer without obvious mange-compatible lesions revealed only 4 seropositive animals. All 83 sera from hunting preserves without clinical cases yielded negative ELISA results. According to these epidemiological data mange does not seem to threaten red deer populations in Asturias. However, continued monitoring of deer health and ELISA testing for sarcoptic mange is advisable.
\end{abstract} (C) 2008 Elsevier B.V. All rights reserved.

Keywords: Cervus elaphus; Emerging disease; Monitoring; Scabies; Shared disease

\section{Introduction}

Concern about emerging diseases has risen in recent years, and multihost situations have become increasingly relevant for wildlife management and conservation (Gortázar et al., 2007). Sarcoptic mange is a highly

\footnotetext{
* Corresponding author. Fax: +34 926295451.

E-mail address: Christian.Gortazar@uclm.es (C. Gortázar).
}

contagious skin disease affecting seven different mammalian orders, including humans (Arlian, 1989). The etiological agent is an obligate parasitic mite of the skin, Sarcoptes scabiei (Linnaeus 1758), that causes skin inflammation, pruritus, and usually cutaneous hypersensitivity leading sometimes to excoriation, exudation and even haemorrhage (Collebrook and Wall, 2004). As a consequence of physiological alterations in skin and different organs (Arlian et al., 1990) the host often becomes dehydrated and ema- 
ciated, and can finally succumb to the infestation (Pence and Ueckerman, 2002).

In many animal species, the prevalence of scabies is very high and often causes death if it is untreated (Brotowijoyo, 1987; Kemp et al., 2002). It is an important disease in cattle, pigs, sheep and goats worldwide, with many economical implications in prophylaxis and treatment (Alonso de Vega et al., 1998; Rehbein et al., 2003; Tarigan and Huntley, 2005; Menzano et al., 2007). Sarcoptic mange seems to show more dramatic effects in wildlife, severely affecting the population dynamics of different species (Mörner, 1992; Balestrieri et al., 2006). This parasitic disease has frequently been reported in wild Bovidae populations throughout Europe: chamois (Rupicapra rupicapra) and ibex (Capra ibex) in the Alps (e.g. Onderscheka, 1982; Schaschl, 2003; Rossi et al., 2007), Iberian ibex (Capra pyrenaica) in southern and eastern Spain (Leon Vizcaino et al., 1999), and the introduced Barbary sheep (Ammotragus lervia) in south-eastern Spain (González-Candela et al., 2004). A mange epizootic mainly affecting Southern chamois (Rupicapra pyrenaica parva) in the Cantabrian Mountains, northern Spain, was first detected in 1993 and is still expanding eastwards today (Fernández-Moran et al., 1997). Since the onset of the outbreak until 2006 a total of 1515 mangy chamois have been detected in Asturias.

The Iberian red deer (Cervus elaphus hispanicus) populations are increasing during recent years (Gortázar et al., 2000). In Asturias, northern Spain, the last autochthonous red deer were hunted in the first decade of 20th century, but red deer were successfully reintroduced between 1955 and 1974 with animals from the remaining indigenous populations in Central Spain (Nores and Vázquez, 1987; Pérez et al., 1998; Acevedo, 2006).

Sarcoptic mange transmission has been documented from chamois to red deer, roe deer (Capreolus capreolus) and Alpine ibex by Kutzer (1966), and from Iberian ibex to red deer, fallow deer (Dama dama) and mouflon (Ovis aries musimon) by Leon Vizcaino (Leon Vizcaino et al., 1992). Sarcoptic mange has sporadically been described in red deer in European countries, usually as sporadic cases (Boch and Schneidawind, 1988; Rossi et al., 2007). Outbreaks with more than 4 red deer affected by sarcoptic mange have only been described in Austria (Kutzer, 1966; Köhler, 1970; Greßmann, 2001) and in Spain during the sarcoptic mange epizootic affecting Iberian ibex in the Cazorla Natural Park since 1987 (Leon Vizcaino et al., 1992).

During the last decade an increasing number of mangy red deer have been observed in south eastern Asturias
(Cantabrian Mountains, Northern Spain). Although other cervid species, such as roe deer, have been affected in the same area (Oleaga et al., 2008), the number of mangy red deer found since the beginning of the epizootic in chamois (1993) in Asturias, and the small area where all these cases were reported prompted a study of the known cases. The aim of this paper is to compile this information and use an in house ELISA test to establish if sarcoptic mange is an emerging disease in deer.

\section{Material and methods}

\subsection{Study area}

The Principality of Asturias is a $10,603 \mathrm{~km}^{2}$ autonomous region located in the North of the Iberian Peninsula, including the central part of the Cantabrian mountain chain. This area includes 17 public game reserves. These reserves have a total surface area of $2110 \mathrm{~km}^{2}$ and contain most of the red deer and chamois ranges in the region (Fig. 1).

One of these 17 reserves is the Regional Game Reserve of Caso $\left(43^{\circ} 06^{\prime} \mathrm{N}, 005^{\circ} 15^{\prime} \mathrm{W}\right.$; number 10 in Fig. 1), that covers $307 \mathrm{~km}^{2}$ and is located in southwestern Asturias. This is the core area of the deer mange cases reported herein. It is surrounded by the game reserves of Aller (223 $\mathrm{km}^{2}$, number 9) and Sobrescobio $\left(67 \mathrm{~km}^{2}\right.$, number 17$)$ to the West, Piloña $\left(54 \mathrm{~km}^{2}\right.$, number 11) to the North and Ponga $\left(205 \mathrm{~km}^{2}\right.$, number 13) to the East, and by the province of León to the South. The relief is mountainous, with altitudes ranging from 800 to $2100 \mathrm{~m}$, and the landscape is the typical of the Orocantabrian region, basically composed of forests (39\%, mainly deciduous woods), shrubs $(39 \%$,$) and$ meadows (16\%).

This region is included in the Eastern nucleus of the Cantabrian chamois distribution area in Asturias and houses other ungulate species including roe deer, red deer and wild boar (Sus scrofa); there can also be found large populations of red fox (Vulpes vulpes), beech marten (Martes martes), stone marten (Martes foina), badger (Meles meles) and wolf (Canis lupus), all of them listed among the hosts of $S$. scabiei in Europe (Todd et al., 1981; Bornstein et al., 2001; Domínguez et al., in press). Cattle are also abundant in the studied area, sharing pasture with wild ruminants, whereas the presence of sheep and goats is almost anecdotal.

\subsection{Monitoring of chamois and red deer}

As a consequence of the chamois sarcoptic mange outbreak detected in 1993, the distribution area of this 


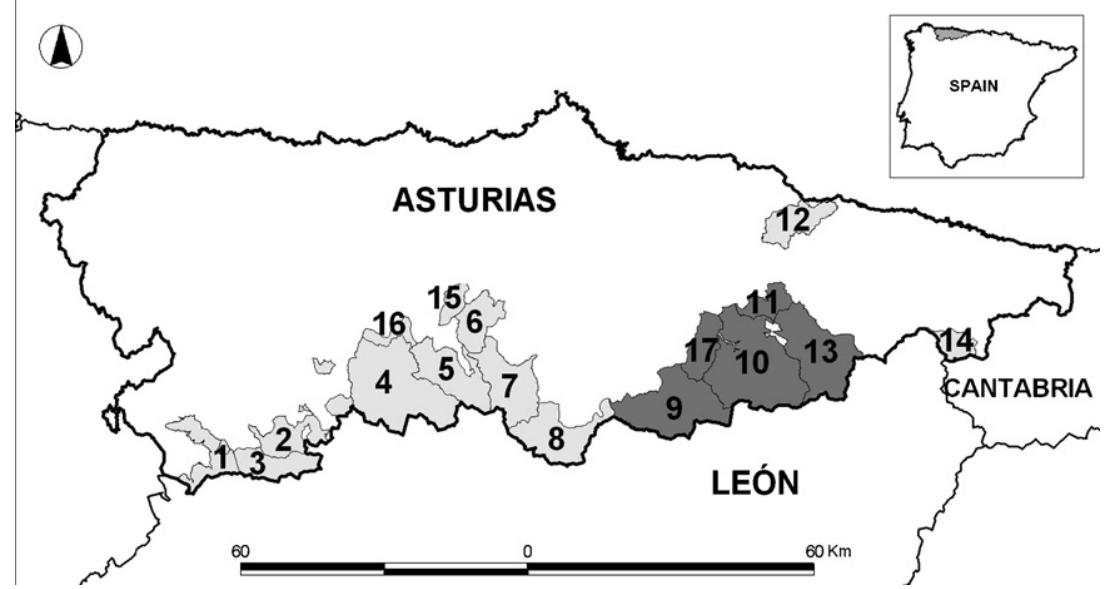

Fig. 1. Map of Asturias showing bordering provinces and numbered game reserves (1: Íbias, 2: Cangas del Narcea, 3: Degaña, 4: Somiedo, 5: Teverga, 6: Proaza, 7: Quirós, 8: Lena, 9: Aller, 10: Caso, 11: Piloña, 12: Sueve, 13: Ponga, 14: Picos de Europa, 15: Yernes y Tameza, 16: Belmonte, 17: Sobrescobio). Those reserves in dark gray are affected by sarcoptic mange in both chamois and red deer. Red deer is almost absent from reserves 1,2 and 3.

bovid has been subjected to a detailed monitoring of both chamois and red deer populations and health status. For this purpose, the distribution area of chamois affected by sarcoptic mange was divided into 15 census sectors ( $\rightarrow O$, see Fig. 6), which belong to game reserves numbers 9, 10, 11, 13 and 17 (Fig. 1).

Red deer population data were obtained from unpublished reports of the Asturias Government, in the frame of regular red deer census made by gamekeepers and technicians in the game reserves. In this case, due to orography and organizational reasons, the already existing division of game reserves in hunting areas was used as red deer census sectors, different from those signalled for the chamois census. According to this information, the red deer population estimated for the 17 reserves of Asturias was 6360 animals in 2006, although abundance and distribution were irregular. Along with areas with a very low or even nil density, with less than 1 individual for 100 ha (game reserves number 1, 2, 3, 7, 8 and 15, Fig. 1), other reserves showed average densities higher than 6 red deer/100 ha (game reserves number 9 , 10 and 11; Fig. 1). Even within a given reserve, densities vary locally. For example, deer densities in Caso (reserve number 10) ranged from 1.8 to $14.7 / 100$ ha. The hind to stag ratio in the Caso hunting reserve was 1.62 hinds per stag in 2006, while the age ratios reported for this reserve were 0.2 fawns per all-age deer and 0.4 young (less than 2 years) animals per adult.

\subsection{Data on clinical mange in deer}

Data on mangy red deer were recorded by the technician in charge of the chamois and deer monitoring in Asturias (Pablo González-Quirós, Biogestión). Since 1993 to date, the total number of deer showing visible scabies lesions or any other anomalies and their location were recorded. For the description and comparison of sarcoptic mange distribution area in both chamois and red deer we used the minimum convex polygon (MCP) method, i.e. the smallest (convex) polygon containing all points where mangy animals where detected during a given period. A selective culling programme was conducted for animal welfare reasons, shooting animals with visible scabies. Age, sex and any other information available were recorded from deer (a) found dead, (b) hunted with scabies-compatible lesions, or (c) observed with scabies-compatible lesions (Fig. 2). Although sarcoptic mange is not the only possible cause of alopecia in red deer, no other sanitary problem affecting skin condition has been described in ungulates in the study area. A confirmatory laboratorial diagnosis was performed whenever skin sample collection was possible.

\subsection{Mange diagnosis in clinical cases}

In 15 cases, skin samples of $5 \mathrm{~cm} \times 5 \mathrm{~cm}$ were taken from the edges of the lesions, including both healthy and altered tissues, processed in a $10 \% \mathrm{KOH}$ solution for $60 \mathrm{~min}$ at $37^{\circ} \mathrm{C}$ and examined using a light microscope, for the identification of mites according to Wall and Shearer (1997). Additional skin sections were fixed in $10 \%$ buffered formalin for routine histopathology (Hematoxyline-Eosine). In three cases it was possible to perform complete necropsies, paying special attention to any lesions connected with sarcoptic mange. 

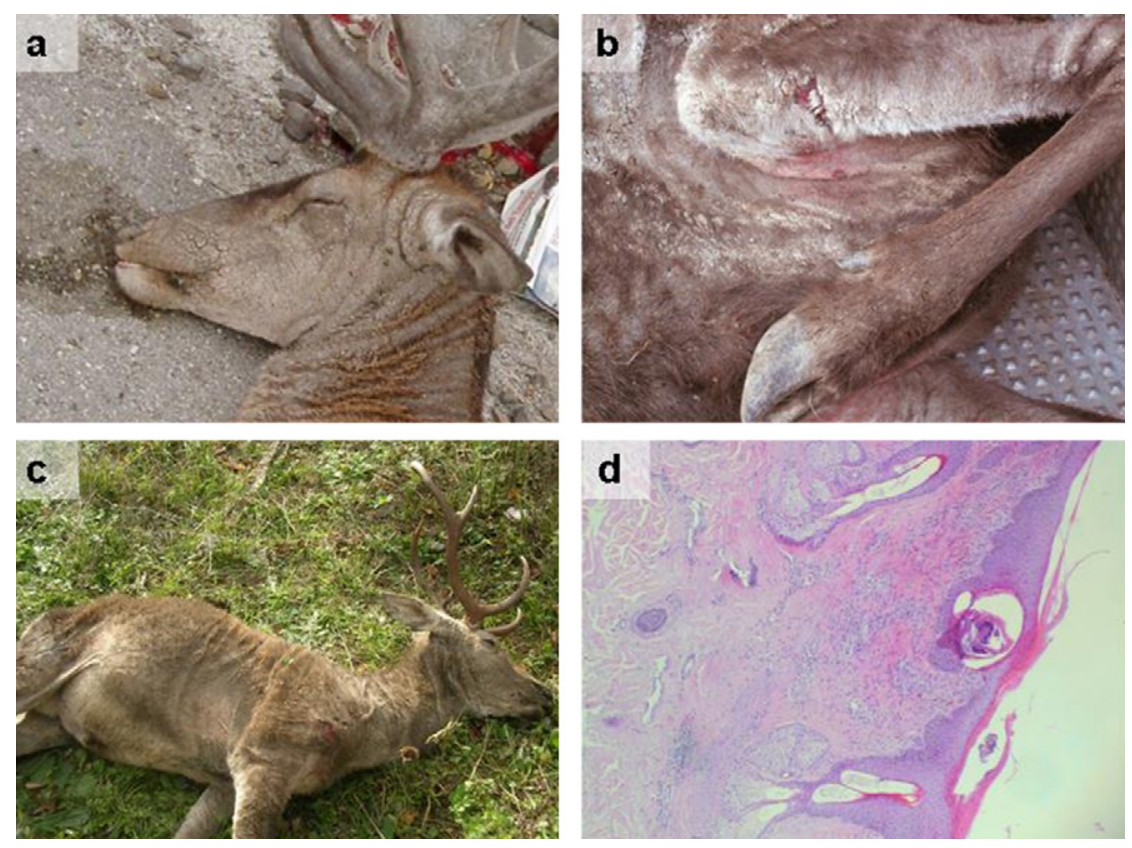

Fig. 2. Sarcoptic mange lesions in red deer: (a) skin crusts and alopecia in head region; (b) hyperkeratosis, skin crusts and cracking in chest and foreleg; (c) hyperkeratosis, alopecia and poor body condition; (d) histology of the skin revealing hyperkeratosis and intracorneal tunnels containing mites.

\subsection{ELISA test}

A total of 418 red deer serum samples collected from 2002 to 2006 were available for testing. Blood was taken from the thoracic cavity, and serum was obtained after coagulation and centrifugation and stored at $-20{ }^{\circ} \mathrm{C}$ until tested by ELISA. Most sera $(n=410)$ were randomly obtained by technicians or gamekeepers during the regular hunting season from apparently healthy red deer, while 8 samples were obtained from clinical mange cases. Sera from the 410 apparently healthy red deer were collected in 11 different preserves. Out of these, 327 sera came from preserves with mange reports (104 sera from game reserve number 10, 61 from \# 17, 74 from \#11, 70 from \#13 and 18 from \#9). The remaining 83 sera came from reserves with no previous mange reports in red deer or chamois (41 from game reserve number 12, 4 from \#4, 2 from \#7, 24 from \#5, 10 from \#6 and 2 from \#2).

All 418 sera were tested for the detection of specific antibodies to $S$. scabiei using a recently developed ELISA test (Casais et al., 2007). This ELISA is based on a structural antigen of the mite (Ss $\lambda 20 \Delta \mathrm{B} 3)$, whose encoding cDNA was identified in a S. scabiei var. hominis library using the sera from an infected chamois and expressed in Escherichia coli as a unitary recombinant antigen. The ELISA method, for its use in the immunodiagnosis of the disease in deer, was validated with a panel of 41 deer sera (33 from healthy unexposed animals originating from a scabies-free area outside Asturias and 8 that were obtained from scabieitic animals) and its cut off level established as a relative optical density (OD) value of 0.43 . With this validation panel, the ELISA test was characterized as having $75 \%$ sensitivity and $97 \%$ specificity.

\subsection{Statistics}

We used Spearman's rank correlation test to detect any relationship between data on monthly temperature, rainfall and snow cover and the number of deer mange cases from 1995 to 2007 (data provided by "Instituto Nacional de Meteorología" I.N.M., Caso station). Prevalence data were compared between age and sex categories with the chi square test.

\section{Results}

S. scabiei was isolated for the confirmation of mange from 13 of 15 skin samples. Bacterial infections (secondary to an important injury in one case) were the cause of cutaneous alteration in the two negative samples.

Detailed necropsies were performed on 3 of the 13 confirmed cases, corresponding to two adult males and an adult female with different degrees of disease 
(Fig. 2). The first animal was an adult male shot in January 2006 by game keepers after observing skin lesions compatible with sarcoptic mange. The affected skin area was about $30 \%$ of the body surface, and the body condition was fair (kidney fat index KFI $=0.79$ ). No other macroscopic lesions or alterations apart from the injured skin were detected.

The second case was also an adult male found shot by poachers in December 2006. This animal presented a pitiful body condition, with $95 \%$ of the body surface affected by alopecia, cutaneous crusts, hyperkeratosis due to sarcoptic mange and presence of a large number of ticks (the estimation was more than 200). Apart from the almost complete absence of fat, confirmed by a KFI value of 0.11 , a general lymphadenitis and many pulmonary and hepatic parasites (Dyctiocaulus sp. and Fasciola hepatica) were detected.

The last case was an adult female shot in February 2007 in an ordinary hunt. A small lesion of $10 \mathrm{~cm} \times 15 \mathrm{~cm}$ containing mites (isolated in the laboratory) was detected in the posterior right leg during inspection. Body condition was fair, with a KFI of 0.92 . The animal was pregnant, with a male foetus, and no significant alteration was detected during necropsy.

The first affected deer appeared in April 1995, when a mangy stag was detected and subsequently shot by rangers. Sarcoptic mange was confirmed in the laboratory. Another three affected red deer were described during that year in the same area, very close to the location of the second outbreak of sarcoptic mange detected in Asturian chamois in the spring of 1994 (see Fig. 3). Since then, 76 cases have been reported up to March 2007, affecting altogether the game reserves number 10, with 60 mangy animals, \#17 with 3 animals, \#13 with 10 animals, \#11 with 3 animals, \#9 with 3 animals and Laviana Council (1 mangy animal). Out of these 80 mangy red deer, 12 $(15 \%)$ were field observations of deer with lesions, 20 $(25 \%)$ were shot deer and $48(60 \%)$ were deer that were found dead in the field.

No significant relationship was detected between monthly temperatures, rainfall or number of days with snow cover and the annual number of sarcoptic mange cases in red deer during the period under study $(p>0.05)$. These findings may have been due to the lack of a complete series of data.

The first mangy stag appeared in April 1995, inside the area affected by the second nucleus of the chamois sarcoptic mange outbreak detected in 1994 in Asturias. Since then, only 4 out of the 80 affected red deer (5\%) were detected outside the limits of scabietic chamois distribution during the same year, and all of them were less than $2500 \mathrm{~m}$ away from that limit (estimated using the method of the minimum convex polygon). The longest distance reported between two consecutive mangy deer locations was $18 \mathrm{~km}$ and occurred between 1995 and 1996 (Fig. 3). These kinds of "jumps" of the disease were observed at least twice more (1997 and 2000). Sporadic cases near to previously reported ones appeared all over the study area until 2001. Since then, the pattern of appearance of new cases seems to have changed, with an apparent concentration of mangy animals in the Nalón river valley in the Caso game reserve. Out of the total 38 mangy animals described between 2002 (year with the maximum number of scabietic red deer reported, 16 cases) and 2007, 37 were located no farther than $2 \mathrm{~km}$ from Nalón river, and only 1 appeared in the Ponga Game Preserve in 2003, $10 \mathrm{~km}$ away (Fig. 3).

Four out of the five game reserves where deer mange has been described (number 9, 10, 11 and 13) have the highest values of red deer density observed in all Asturian game reserves (there is no data for the fifth affected one, game reserve number 17 , where game keepers also signal a high density rate).

Out of the total 73 adult mangy animals, 48 (67.6\%) were stags and only $23(32.4 \%)$ hinds, while in two cases the sex was unknown. Considering the hind to stag ratio reported for the Caso preserve (1.62), the expected number of cases was 28 stags and 45 hinds. Hence, this difference was statistically significant $\left(\mathrm{Chi}^{2}=11.2,1\right.$ d.f., $p<0.001)$. During the study period, from 1995 to 2007 (Fig. 6), mange cases were not uniformly distributed throughout the year: $56.4 \%$ of total described cases $(55.3 \%$ stags, $54.1 \%$ hinds and $71.4 \%$ young animals) were registered from January to April, with a maximum of 16 mangy animals in January (10 stags, 3 hinds and 3 young animals) and a minimum of 1 single stag in October (Fig. 4).

From 1999 to 2007 the number of scabietic young animals (two or less years old) was 7 (4 males and 3 females) out of a total of 56 (39 males and 17 females). Considering the age ratio reported for Caso ( 0.4 young per adult), the expected proportion was 16 cases in young deer and 39 in adults. The difference was also statistically significant $\left(\mathrm{Chi}^{2}=4.45,1\right.$ d.f., $\left.p<0.05\right)$.

Fig. 5 shows the area affected by deer and chamois mange and the number of cases recorded per year. It becomes evident that, while chamois mange showed a marked epidemic wave from 1994 to 2001, deer mange showed a rather continuous graph of 1-16 (mean 5) annual cases. Moreover, while the area of chamois mange steadily increased, the area of deer mange remained rather constant. 


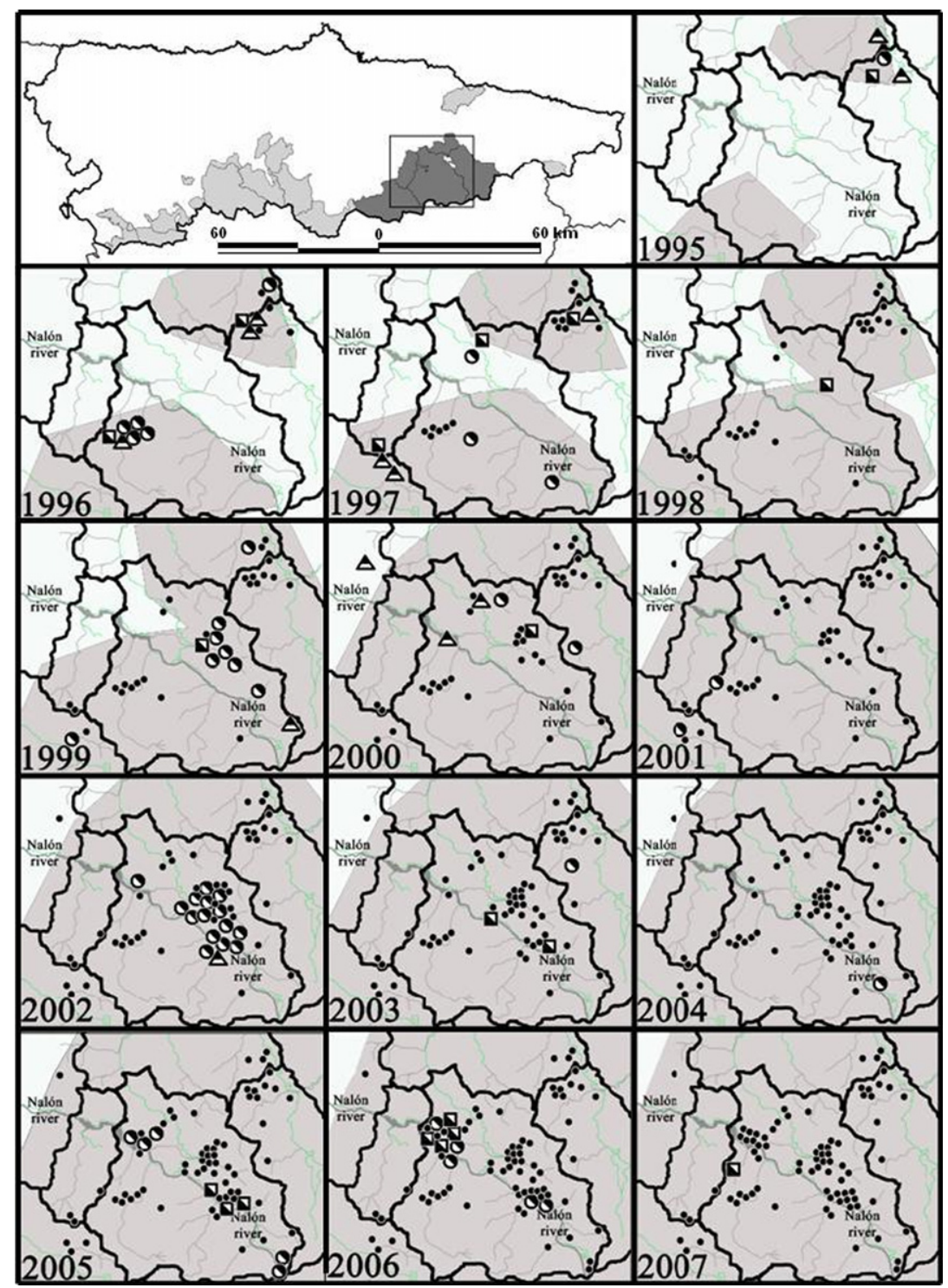

Fig. 3. Detected mangy red deer found dead $(\boldsymbol{O})$, shot $(\boldsymbol{\nabla})$ and observed with sarcoptic mange compatible lesions $(\boldsymbol{\Delta})$ in Asturias during the study period (1995-2007). Dots ( ) represent cases in preceding years. The shaded area represents the chamois sarcoptic mange distribution area.

Mange cases in deer appeared most often 1-3 years after the first chamois mange cases (range 0-4 years; Fig. 6). In $50 \%$ of the affected sectors (5 out of 10 ) mange cases in deer have been reported at least in 4 different years, with a maximum of 7 years with mangy cervids in one single sector (Fig. 6).

In the mange affected area, ELISA testing of 327 blood samples from apparently healthy hunter-harvested deer without obvious mange-compatible lesions revealed only 4 seropositive animals: two in game reserve number 10 (Caso), one in number 17 (Sobrescobio) and one in number 13 (Ponga). All 83 sera from hunting preserves without clinical cases yielded negative ELISA results. Of the 8 sera from clinical mange cases, only 6 tested positive at the established cut-off value. Those testing negative belonged to a stag and a hind in poor body condition. The obtained average relative OD value \pm standard deviation was: $0.76 \pm 0.48$ for mangy animals, $0.01 \pm 0.03$ for apparently healthy animals from areas without mange, and $0.02 \pm 0.06$ for apparently healthy animals from areas exposed to sarcoptic mange.

\section{Discussion}

Despite the limited number of cases (80) during a period of 13 years, this is to our knowledge the highest 


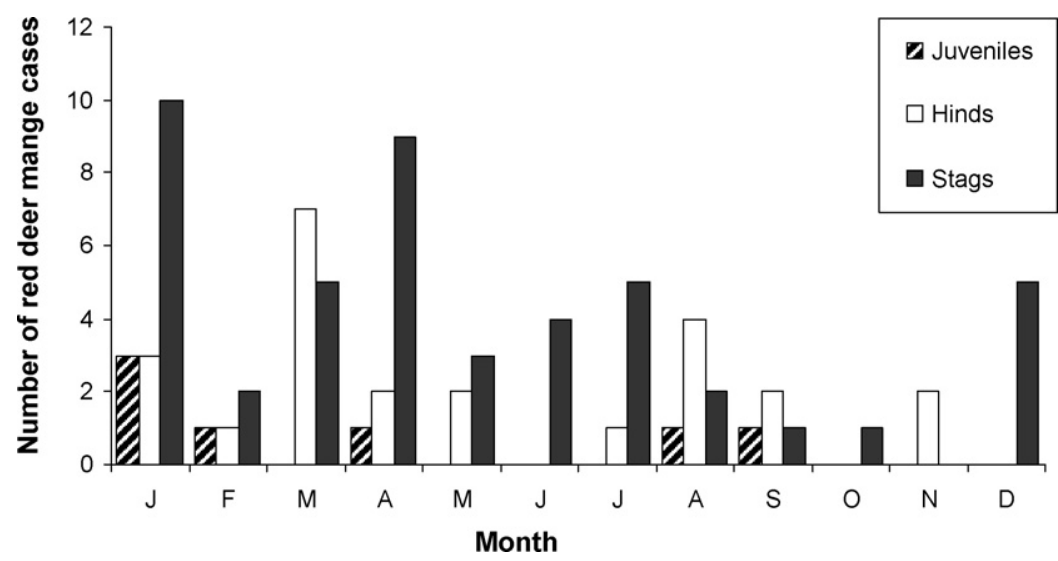

Fig. 4. Distribution of red deer sarcoptic mange cases by age, class and month (Asturias, 1995-2007).

concentration of mange cases ever reported in European deer. The present report is the first epidemiological description of sarcoptic mange in red deer from Spain, and one of the few reports with a high number of affected deer in Europe.

One of the features signalled in the study is the high proportion of dead or severely affected animals in comparison with those observed as slightly affected or without clinical signs but confirmed as scabietic in laboratory by isolation of mites or shown to have been in contact with mange using serological techniques; this seems to differ from descriptions of other red deer populations affected by scabies where a higher proportion of slightly affected red deer has been reported (Leon Vizcaino et al., 1992).

The presence of 2 skin samples negative for mite isolation from the total of 15 taken for detection of $S$. scabiei confirms that some field reports of affected deer may not be due to mange. Nevertheless, although the existence of false positives (due to incorrect diagnostic in the field or lack of laboratorial confirmation) must be taken into account, the number of mangy animals was probably underestimated because of the woody and rocky study area, as described in other scabies affected wildlife populations (Rossi et al., 2007).

Taking into account the references to sarcoptic mange cases reported in red deer in Austria from 1969 to 1993 (Greßmann, 2001) and in Cazorla (Spain) in 1991 (Leon Vizcaino et al., 1992), this is the largest succession of cases described in Europe (80 cases so far) and the second longest (with a 13 year duration up to the present, 1995-2007). Our data confirm the annual trend observed in other sarcoptic mange epidemics from European ungulates (Fernández-Moran et al., 1997; Gortázar et al., 1998; González-Quirós et al., 2002; Rossi et al., 2007) where the largest amount of affected

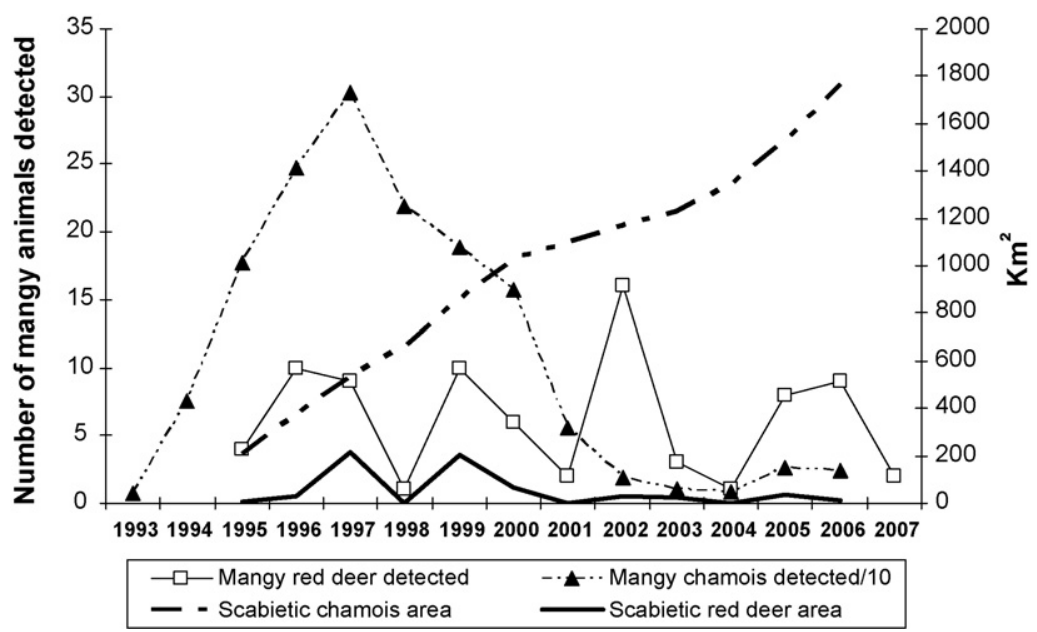

Fig. 5. Number of sarcoptic mange cases in chamois and red deer and affected surface (in $\mathrm{km}^{2}$ ) in Asturias from 1995 to 2007. 


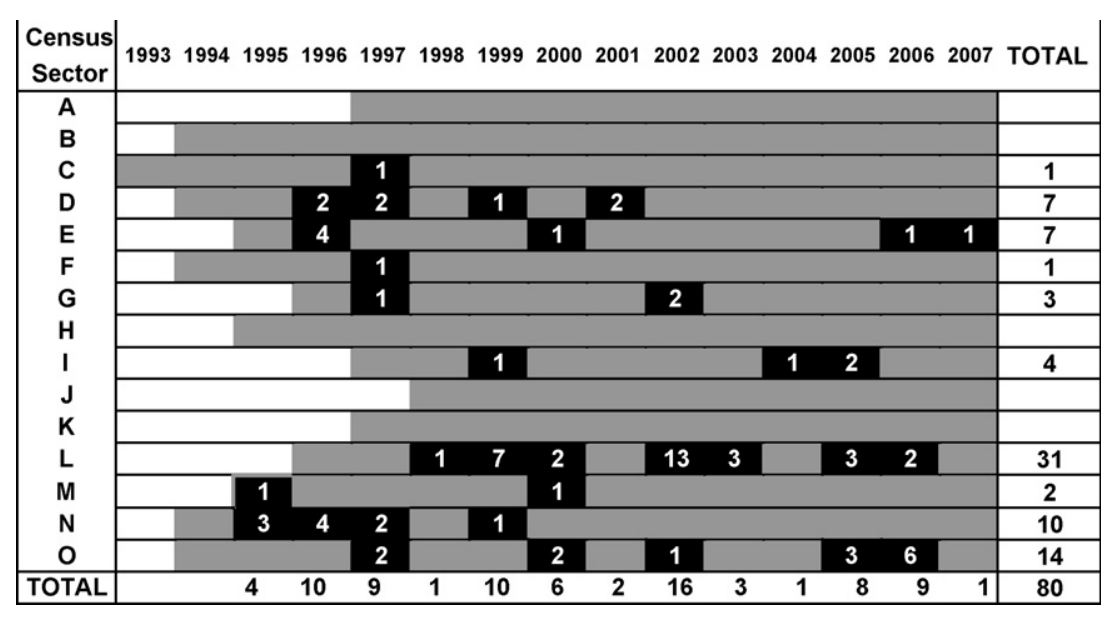

Fig. 6. Temporal relationship between the first detection of chamois mange and first detection of scabietic red deer. Gray cells signal presence of sarcoptic mange in chamois. White numbers inside black cells indicate the number of mangy red deer detected for that year in a census sector.

animals was detected at the end of winter and spring, is due to mite (that seems to prefer humidity and low temperatures present in this season for satisfactorily completing its life-cycle, Sokolova et al., 1989), host (whose body condition is usually worse at this time of the year, Loison and Langvatn, 1998) and ecological characteristics. However, the evolution of illness during the studied period differs from that observed in chamois. Instead of a long cycle (about 15 years in Alpine chamois) with a peak in the number of affected individuals 4-6 years after the beginning of the outbreak and a slow and continuous decrease in morbidity and mortality during the following years (Fernández-Moran et al., 1997; González-Quirós et al., 2002; Rossi et al., 2007), in the case of red deer we observed sporadic cases for a long time.

The first case in deer always appeared between 0 and 4 years after the arrival of sarcoptic mange to the local chamois population. Although this value is similar to that reported for first cases in hosts different than chamois in a scabies epidemic described in Italy (Rossi et al., 2007), a difference observed in Asturias is that mangy red deer have been reported 12 years after the first described case.

The detection of the first mangy deer cases just 1 year after the beginning of the chamois sarcoptic mange outbreak in one of the foci and 3 years after in the other one, strongly suggests that the origin of red deer mange is chamois. This hypothesis is supported by the fact that $95 \%$ of the affected deer were detected within the limits of the scabietic chamois distribution area for any given year.

In contrast with the "oil spot" advancement of the disease signalled for other wild ruminants (Rossi et al.,
2007), sarcoptic mange in red deer usually appeared as a disorganized succession of cases, isolated or in clusters of up to 6 animals per year (Fig. 3).

No epidemiological explanation has been found for the spatial concentration of mangy red deer cases reported around the Nalón River in the Caso (\#10) game reserve since 2002. A similar trend in the distribution of mangy red deer detected was reported in Austria (Köhler, 1970; Greßmann, 2001) where most of the carcasses and diseased animals appeared near a river or road, or even close to feeding troughs used in this area during winter. This kind of place is also more accessible and frequented by people, facilitating detection of animals or carcasses. However, this pattern of spatial concentration has not been observed along other roads, rivers or valleys in the sarcoptic mange affected area in Asturias. No significant variation or difference with other surrounding localities has been detected in this limited area regarding red deer or chamois densities, scabies incidence on chamois population, habitat quality or even search effort.

The explanation for the restriction of mange cases in red deer to the signalled game reserves is unknown. With the advancement of the epidemic in chamois new sympatric red deer populations have been exposed to $S$. scabiei not only in Asturias, but also in León and Cantabria in recent years (Fig. 1), without the detection of new cases. Density (Rossi et al., 1995; Guberti and Zamboni, 2000), population health level (Gortázar et al., 1998; Leon Vizcaino et al., 1999), and geneticbased variations in mite virulence and host resistance to mange (Pence and Windberg, 1994; Berrilli et al., 2002) have been suggested as possible factors determining appearance and evolution of sarcoptic mange. 
The fact that the affected reserves are of high deer density may indicate the existence of a relationship between red deer population density, the risk of sarcoptic mange appearance and the morbidity rate in red deer (suggesting overabundance, e.g. Gortázar et al., 2006). However, density-reactive indicators of fitness such as KFI, parasitation levels, trophy and body measurements, or fertility rates estimated by 138 complete red deer necropsies carried out by the authors in the affected and unaffected areas in Asturias show no significant difference, suggesting no relation of these factors with deer mange (data not shown).

A difference with mange outbreaks in other European ungulates (Fernández-Moran et al., 1997; Leon Vizcaino et al., 1999; Greßmann, 2001; Rossi et al., 2007) was that males showed a higher morbidity than females. Physiological characteristics (i.e. the immunocompetence handicap hypothesis) and differences in behavior between sexes (different roles in activities related to sexual selection, different exposure to parasites due to feeding habits and habitat use) may explain this sex related bias (Vicente et al., 2007).

The low proportion of mangy juveniles agrees with previous reports. However difficulty of observation, higher mortality rates and easier disappearance of the carcasses must also be taken into account (FernándezMoran et al., 1997).

Although the existence of temporal and spatial coincidence between chamois and deer sarcoptic mange emergence strongly suggests that the origin of red deer mange is chamois mange, prevalence curves show an independent evolution and maintenance of disease in both species.

The red deer has been signalled by different authors (Leon Vizcaino et al., 1992; Rossi et al., 2007) as a possible "supplementary host" for S. scabiei. Even though this mite shows host specificity, the presence of high densities of red deer in the habitat of its most important host (namely caprines) in Spain may have made these parasite strains able to infect this species when chamois densities are low, potentially improving mite strain survival. This hypothetical "adaptation" to deer is consistent with the detection of 2 roe deer (a very unusual host of $S$. scabiei) severely affected by mange in the same area (Oleaga et al., 2008).

The presence of two confirmed mangy animals with seronegative results in the ELISA test highlights the probable existence of false negative animals in the serosurvey. The existence of diseased seronegative individuals is a common problem in surveillance and control programs of debilitating illnesses, due usually to the existence of immunocompromised or anergic animals (Pence and Ueckerman, 2002; Fernández-deMera et al., 2006).

All four positive sera of the ELISA testing of 410 blood samples from apparently healthy hunter-harvested deer belonged to the area where mangy red deer had already been described, confirming the absence of deer mange outside the chamois mange range. However, further testing is advisable to continue monitoring the disease.

Only a small number of seropositive animals were found among randomly shot deer. This suggests (a) that most deer infected with $S$. scabiei do develop clinical disease, (b) that most mangy red deer die as a consequence of the disease, or alternatively quickly lose antibodies after overcoming sarcoptic mange, and (c) that the ELISA test may be unfit to reveal the low mite loads of "healthy carrier" deer. However, we found no animals in apparent clinical recovery. Our findings emphasize the need of epidemiological studies and experimental infections to better understand sarcoptic mange epidemiology in red deer.

\section{Conclusions}

Both serology and recorded clinical cases suggest low morbidity and high mortality due to sarcoptic mange in studied deer populations. Attending to these epidemiological characteristics scabies does not seem to threaten red deer populations in Asturias. However, available data do not allow to predict if scabies will become extinct or progress, or if it could turn into an endemic problem.

Data recorded in this paper indicate no disease emergence. Thus, recommending special measures does not appear necessary. Nevertheless, monitoring of deer sanitary condition and ELISA testing for sarcoptic mange are advisable.

\section{Acknowledgements}

This is a contribution to the agreement between CSIC and Principado de Asturias and MEC research grant AGL2005-07401. We thank the rangers of the game preserves, technicians working for the Asturias Government and our colleagues from SERIDA and IREC for their assistance in field and laboratory work. The authors wish to thank Kevin Dalton for revising the English and Pelayo Acevedo for his contribution in geographical analysis and maps design. Special thanks to Patricia Álvarez for her patience. 


\section{References}

Acevedo, P., 2006. Ecogeografía de la cabra montés (Capra pyrenaica): relación con otros ungulados en simpatría en el centro-sur de la Península Ibérica. Tesis doctoral. I.R.E.C., Universidad de Castilla la Mancha, España.

Alonso de Vega, F., Mendez de Vigo, J., Ortiz Sanchez, J., MartinezCarrasco Pleite, C., Albaladejo Serrano, A., Ruiz de Ybanez Carnero, M.R., 1998. Evaluation of the prevalence of sarcoptic mange in slaughtered fattening pigs in southeastern Spain. Vet. Parasitol. 76, 203-209.

Arlian, L.G., 1989. Biology, host relations, and epidemiology of Sarcoptes scabiei. Ann. Rev. Entomol. 34, 139-161.

Arlian, L.G., Bruner, R.H., Stuhlman, R.A., Vyszenski-Moher, D.L., 1990. Histopathology in hosts parasitized by Sarcoptes scabiei. J. Parasitol. 76, 889-894.

Balestrieri, A., Remonti, L., Ferrari, N., Ferrari, A., Valvo, T.L., Robetto, S., Orusa, R., 2006. Sarcoptic mange in wild carnivores and its co-occurrence with parasitic helminths in the Western Italian Alps. Eur. J. Wildlife Res. 52 (3), 196-201.

Berrilli, F., D'Amelio, S., Rossi, L., 2002. Ribosomal and mitochondrial DNA sequence variation in Sarcoptes mites from different hosts and geographical regions. Parasitol. Res. 88, 772-777.

Boch, J., Schneidawind, H., 1988. Krankheiten des jagdbaren Wildes. Paul Parey, Hamburg and Berlin, 398 pp.

Bornstein, S., Morner, T., Samuel, W.M., 2001. Sarcoptes scabiei and sarcoptic mange. In: Samuel, W.M., Pybus, M.J., Kocan, A.A. (Eds.), Parasitic Diseases of Wild Mammals. 2nd ed. Iowa State University Press, Ames, pp. 107-119.

Brotowijoyo, M.D., 1987. Scabies pada hewan dan permasalahannya. Bull. FKH UGM 7, 1-5.

Casais, R., Prieto, M., Balseiro, A., Solano, P., Parra, F., MartínAlonso, J.M., 2007. Identification and heterologous expression of a Sarcoptes scabiei cDNA encoding a structural antigen with immunodiagnostic potential. Vet. Res. 38, 435-450.

Collebrook, E., Wall, R., 2004. Ectoparasites of livestock in Europe and the Mediterranean region. Vet. Parasitol. 120, 251-274.

Domínguez, G., Espí, A., Prieto, J.M., de la Torre, J.A. Sarcoptic mange in wolves (Canis lupus signatus) from Northern Spain (Burgos). Vet. Rec., in press.

Fernández-de-Mera, I.G., Höfle, U., Vicente, J., Garcia, A., Rodríguez, O., Gortázar, C., 2006. Optimal dose and timing in phytohaemagglutinin skin-testing of deer. New Zeal. Vet. J. 54 (6), 357 359.

Fernández-Moran, J., Gomez, S., Ballesteros, F., Quirós, P., Benito, J.J., Feliu, C., Nieto, J.M., 1997. Epizootiology of sarcoptic mange in a population of cantabrian chamois (Rupicapra pyrenaica parva) in Northwestern Spain. Vet. Parasitol. 73, 163-171.

González-Candela, M., Leon Vizcaino, L., Cubero-Pablo, M.J., 2004. Population effects of sarcoptic mange in Barbary sheep (Ammotragus lervia) from Sierra Espuña Regional Park. Spain. J. Wildlife Dis. 40, 456-465.

González-Quirós, P., Silva Manzano, P., Solano Rodríguez, S., 2002. Population evolution of Cantabrian chamois (Rupicapra pyrenaica parva) with sarcoptic mange (Sarcoptes scabiei) in centre-eastern Asturias (Northwest Spain). Pirineos 157, 201-209.

Gortázar, C., Villafuerte, R., Blanco, J.C., Fernández-de-Luco, D., 1998. Enzootic sarcoptic mange in red foxes in Spain. Zeitschr. Jagdwissensch 44, 251-256.

Gortázar, C., Herrero, J., Villafuerte, R., Marco, J., 2000. Historical examination of the status of large animals in Aragón, Spain. Mammalia 64 (4), 411-422.
Gortázar, C., Acevedo, P., Ruiz-Fons, F., Vicente, J., 2006. Disease risks and overabundance of game species. Eur. J. Wildl. Res. 52 (2), 81-87.

Gortázar, C., Ferroglio, E., Höfle, U., Frölich, K., Vicente, J., 2007. Diseases shared between wildlife and livestock: a European perspective. Eur. J. Wildl. Res. 53, 241-256.

Greßmann, G., 2001. Gamsräude und Gamsblindheit: Auftreten in der Steiermark zwischen 1952 und 1999 sowie Schlußfolgerungen für Präventionsmaßnahmen im Rahmen der Jagd. Dissertation, KarlFranzens Universität, Graz.

Guberti, V., Zamboni, L., 2000. Can the host resistance hypothesis explain the cyclic patterns observed in Sarcoptes scabiei in chamois (Rupicapra rupicapra)? Parasitologia 42 (Suppl. 1), 72.

Kemp, D.J., Walton, S.F., Harumal, P., Currie, B.J., 2002. The scourge of scabies. Biologist (London) 49, 19-24.

Köhler, H., 1970. Uber das Vorkommen der Gamsräude beim Rotwild. Eigenverlag, Graz.

Kutzer, G., 1966. Zur epidemiologie der Sarcoptesräude. Angew. Parasitol. 7, 241-248.

Leon Vizcaino, L., Astorga, R., Escos, J., Alonso, F., Alados, C., Contreras, A., Cubero, M.J., 1992. In: Actas del Congreso Internacional del Género Capra en Europa (Ronda, Spain) pp. 95-99.

Leon Vizcaino, L., Ruiz de Ibáñez, M.R., Cubero-Pablo, M.J., Ortiz, J.M., Espinosa, J., Pérez, L., Simon, M.A., Alonso, P., 1999. Sarcoptic mange in Iberian ibex from Spain. J. Wildl. Dis. 35, 647-659.

Loison, A., Langvatn, R., 1998. Short- and long-term effects of winter and spring weather on growth and survival of red deer in Norway. Oecologia 116 (4), 489-500.

Menzano, A., Rambozzi, L., Rossi, L., 2007. A severe episode of wildlife-derived scabies in domestic goats in Italy. Small Ruminant Res. 70, 154-158.

Mörner, T., 1992. Sarcoptic mange in Swedish wildlife. OIE Revue Scientifique et Technique 11 (4), 1115-1121.

Nores, C., Vázquez, V.M., 1987. La conservación de los vertebrados terrestres asturianos. In: Unidades temáticas ambientales. Dirección General de Medio Ambiente, MOPU, 130 pp.

Oleaga, A., Balseiro, A., Gortázar, C., 2008. Sarcoptic mange in two roe deer (Capreolus capreolus) from Northern Spain. Eur. J. Wildl. Res. 54 (1), 134-137.

Onderscheka, K., 1982. Etat actuel de la recherche sur la gale du chamois. In: Proc. Symp. Sur le chamois, Conseil International de la Chase et de la Fauna sauvage, Ljubljana, Yugoslavia, pp. 89108.

Pence, D.B., Windberg, L.A., 1994. Impact of a sarcoptic mange epizootic on a coyote population. J. Wildl. Manage. 58 (4), 624633.

Pence, D.B., Ueckerman, E., 2002. Sarcoptic mange in wildlife. Revue Scient. Techn. l'Office Int. des Epizooties 21, 385-398.

Pérez, T., Albornoz, J., Nores, C., Domínguez, A., 1998. Evaluation of genetic variability in introduced populations of red deer (Cervus elaphus) using DNA fingerprinting. Hereditas 129, 85-89.

Rehbein, S., Visser, M., Winter, R., Trommer, B., Matthes, A.E., Maciel, A.E., Marley, S.E., 2003. Productivity effects of bovine mange and control with ivermectin. Vet. Parasitol. 114, 267-284.

Rossi, L., Meneguz, P.G., De Martin, P., Rodolfi, M., 1995. The epizootiology od sarcoptic mange in chamois, Rupicapra rupicapra, from the Italian Eastern Alps. Parasitologia 37, 233-240.

Rossi, L., Fraquelli, C., Vesco, U., Permunian, R., Sommavilla, G.M., Carmignola, G., Da Pozzo, R., Meneguz, P.G., 2007. Descriptive epidemiology of a scabies epidemic in chamois in the Dolomite Alps, Italy. Eur. J. Wildl. Res. 53 (2), 131-141. 
Schaschl, E., 2003. Gamsräude. Österreichischer Jagd- und Fischereiverlag, Wien, $160 \mathrm{pp}$.

Sokolova, T.V., Radchenko, M.I., Lange, A.B., 1989. The seasonality of scabies morbidity and the fertility of the itch mite Sarcoptes scabiei de Geer as an index of the activity of a population of the causative agent. Vestn. Dermatol. Venerolog. 63 (11), 12-25.

Tarigan, S., Huntley, J.F., 2005. Failure to protect goats following vaccination with soluble proteins of Sarcoptes scabiei: evidence for a role for IgE antibody in protection. Vet. Parasitol. 133, 101109.
Todd, A.W., Gunson, J.R., Samuel, W.M., 1981. Sarcoptic mange: an important disease in coyotes and wolves of Alberta, Canada. In: Worldwide Furbearer Conference Proceedings, Frostburg, Maryland, pp. 706-729.

Vicente, J., Pérez-Rodríguez, L., Gortázar, C., 2007. Sex, age, spleen size and kidney fat of red deer relative to infection intensities of the lungworm Elaphostrongylus cervi. Naturwissenschaften 94, 581587.

Wall, R., Shearer, D., 1997. Veterinary Entomology. Chapman and Hall, London, 439 pp. 